\title{
Determination of Structures for Some Syn and Anti Isomeric Anil Schiff Bases by Some Spectroscopic and Physical Methods
}

\author{
A. S. P. Azzouz ${ }^{1} \&$ D. E. AL-Hyali ${ }^{1}$ \\ ${ }^{1}$ Chemistry Department, College of Education, University of Mosul, Iraq \\ Correspondence: A. S. P. Azzouz, Chemistry Department, College of Education, University of Mosul, Iraq. \\ E-mail: azzouz20042001@yahoo.com
}

\author{
Received: January 8, 2014 Accepted: April 21, 2014 Online Published: June 28, 2014 \\ doi:10.5539/ijc.v6n3p21 URL: http://dx.doi.org/10.5539/ijc.v6n3p21
}

\begin{abstract}
Originally, three aromatic anil Schiff bases were synthesized by reactions of salicylaldehyde with o-,m- and p-phenylene diamine by a standard method, in the presence of azeotrope forming solvent. Two syn and anti isomeric Schiff bases having yellow and orange colors were separated by fractional recrystalization in ethanol, when primary aromatic amine used having o and p-phenylene diamine structures. Mean while m-phenylene diamine gave a single yellow anti isomeric compound.

The main aim of the study was the determination of structures for these five syn and anti Schiff base isomers by the available physical methods. These were performed by using melting points, UV-IR spectra and pKa values for these amphiprotic substances. Results collected in this investigation were interpreted and discussed by proper scientific way depending on experimental data collected.
\end{abstract}

Keywords: aromatic Schiff bases, syn-anti isomers, UV- IR spectra, pKa

\section{Introduction}

A great numbers of imines whether are aliphatic, aromatic or their mixture were prepared during the last years (Patai, 1970; Azzouz et al., 2009, 2011).

Azomethines (Saeed et al., 1979) derived from various carbonyls, $\beta$-ketones, $\beta$-ketoesters, and amine were well known compounds and had been studied extensively (Saeed et al., 1981, 1979, 1983; Saeed, 1984). Several salicylidene Schiff bases had been synthesized by usual method.

Other Schiff bases had been synthesized from salicylaldehyde with plant amino acids. These imines structures had studied (EL-Bindary et al., 1979) by X-ray single crystal.

Most syn and anti isomerism studies were focused on oximes derived from 3-acetyl or 4-acetyl pyridines (Azzouz et al., 2013), 3 or 4-hydroxy benzaldoximes (Azzouz et al., 2012) and $\alpha$-benzil monoxime (Azzouz, 1995).

There were reports (Patai, 1970) of the isolation of anils in more than one crystalline form, usually with different colours and melting points.

The lack of information about structures of syn and anti isomeric anil Schiff bases prepared by reactions of salicylaldehyde with 2, 3, 4-phenylene diamines, prompted this work.

\section{Experimental}

All chemicals were supplied from Fluka or BDH chemical companies. They were used as supplied.

Salicylidene-o-amino aniline, salicylidene-m-amino aniline, and salicylidene-p-amino aniline (Schiff bases numbers 1, 2, and 3 respectively) were prepared by standard method (Vogel, 1978) or by mixing 10-2 molar amounts from salicylaldehyde with $\mathrm{o}, \mathrm{m}$, and $\mathrm{p}$-phenylene diamines in ethanol solvent. These mixtures were refluxed for 1.5 hour, cooled and filtered. Crude Schiff bases products were separated. Upon fractional hot recrystallization in ethanol of Schiff bases number 1 and 3, resulted to the separation of insoluble orange isomers which was recovered by simple filtration. The evaporation of the final filtrate led to the formation of another yellow isomers for these Schiff bases. Schiff base number 2 was recrystallized in the same way as above leading to a single yellow isomer only. 


\section{1 $\mathrm{pKa}$ Determination}

The pKa value of any syn or anti isomer of Schiff base was determined by manufacturing glass cylindrical cell of maximum volume capacity about $30 \mathrm{ml}$.

The cell is contains by two walls for insertion of pumped water from thermostat, to maintain fixed temperature range (288-328) K, during pKa determination.

The whole cell assembly was completely isolated from the surrounding by thick insulation material. $20 \mathrm{ml}$ of $10^{-3} \mathrm{M}$ solution of the Schiff base was placed in the cell. After equilibrium temperature was attained, a successive $0.2 \mathrm{ml}$ of $10^{-2} \mathrm{M}$ of $\mathrm{NaOH}$ was added, till $1.4 \mathrm{ml}$ of base was added, followed by measuring the final equilibrium $\mathrm{pH}$ of solution. The average $\mathrm{pKa}$ values were determined by potentiometric titration method at temperature range stated by applying the following equation:

$$
\mathrm{pKa}=\mathrm{pH}+\log \frac{[\text { acid }]}{[\text { salt }]}
$$

\subsection{Instrumentations}

1) The U.V. spectra of syn and anti Schiff bases were measured by double beam computerized UV 1601 Shimadzu spectrophotometer.

2) The IR spectra of solid and liquid Schiff bases were measured by (FT-600) Biotech engineering Management Co. LTD (UK).

3) Memmert Searl L200 water bath was employed for controlling temperature during pKa study.

4) The $\mathrm{pH}$ of any solution during potentiometric titration was achieved by using Jenway $\mathrm{pH}$ meter model 3516.

\section{Results and Discussion}

At the beginning of this investigation, it was thought of great importance to confirm the structures of the (1-3) Schiff bases and their syn and anti isomers by the available physical means as follow:

1) The UV absorption spectra of 10-4 M Schiff bases (1-3) and their isomers showed that, the Schiff bases 1 and 3 have two isomers of orange and yellow colors. Meanwhile Schiff base (2) has a single yellow color isomer, as in Figure 1. Comparison of the Schiff bases isomers (1 and 3) of the orange and yellow colors as in Table 1, showed the following:

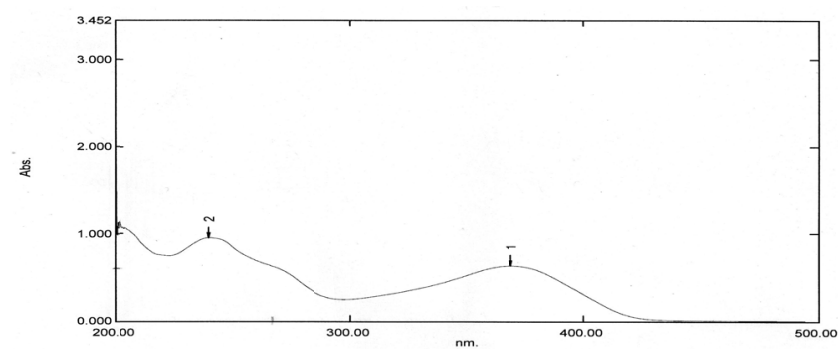

1a. Orange isomer of Schiff base 1

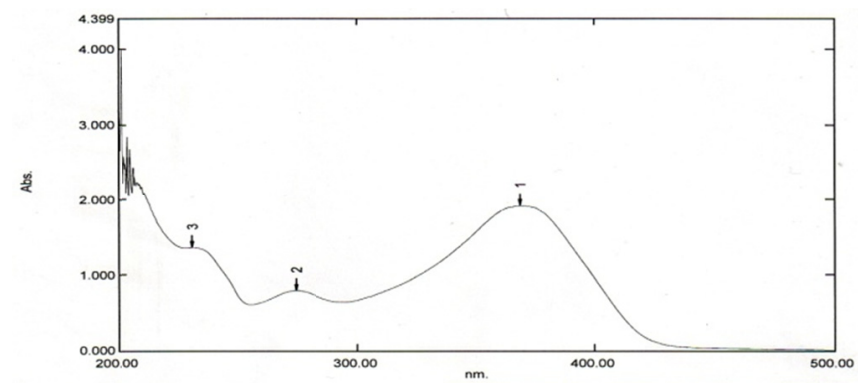

1b. Yellow isomer of Schiff base 1 


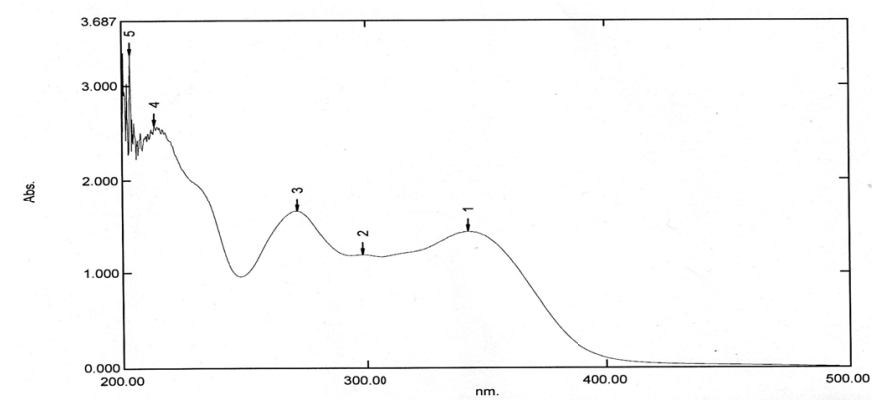

1c. Yellow isomer of Schiff base 2

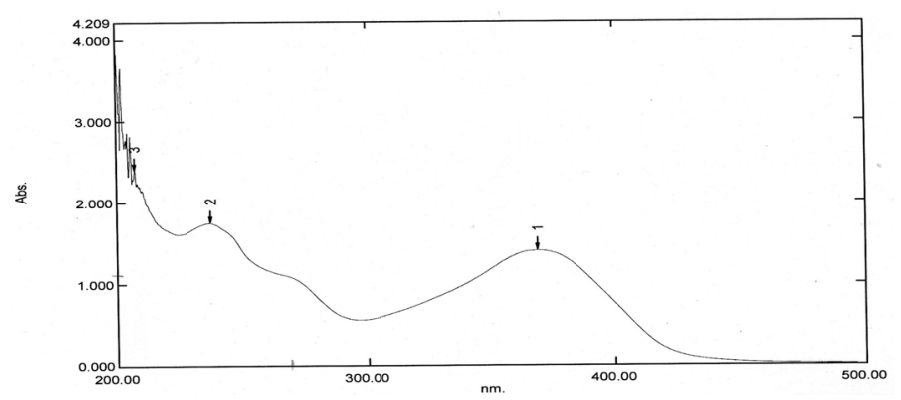

1d. Orange isomer of Schiff base 3

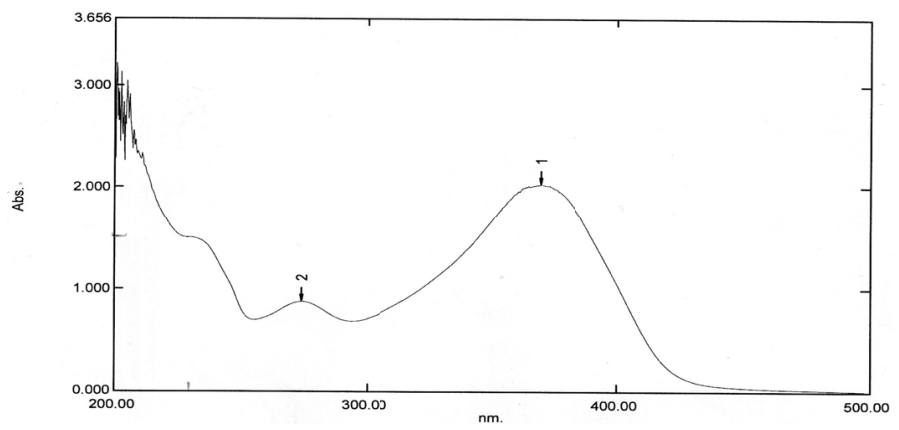

1e. Yellow isomer of Schiff base 3

Figure 1. UV absorption spectra of $10^{-4} \mathrm{M}$ in ethanol

A) Either three absorption bands or two bands with another shoulder were observed for these isomers. These mean that, such isomers of Schiff bases either exist originally in three different planes as clarified by two aromatic ring planes and one plane for azomethine linkages. Similar results were also obtained for mono single yellow isomer of Schiff base number (2).

B) Or the existence of these Schiff bases isomers in two different planes, the first concerned with $\mathrm{Ph}-\mathrm{C}=\mathrm{N}$ linkage and the second was the rest of molecule. The other source of the third absorption in these spectra was examined by measurements of UV spectra of Schiff bases (1-3), followed by addition of two drops of $0.01 \mathrm{~N} \mathrm{NaOH}$. Results collected in this study are shown in Table 2. This showed that, middle or second band in spectra had changed its position.

Table 2 showed that, orange and yellow isomers of Schiff bases 1 and 3 had accompanied by blue shift in their middle bands or negative $\Delta \lambda$ values, as explained by zwitter ion (Majer et al., 1983) formation, whereas a red shift or $\Delta \lambda=$ positive value of Schiff base 2 which confirmed its existence in nitrilium (Azzouz et al., 2012) ion. All these results came in agreement with EL-Bayoumi et al. (1971) finding, concerned with existence of benzylidene aniline Schiff base in two different planes. 
Table 1. UV spectra of $10^{-4} \mathrm{M}$ Schiff bases numbered (1-3) and their isomers in ethanol with melting points

\begin{tabular}{|c|c|c|c|c|c|}
\hline $\begin{array}{c}\text { Schiff Base } \\
\text { Number }\end{array}$ & Colour & Abs. & $\begin{array}{c}\lambda \max \\
(\mathrm{nm})\end{array}$ & $\begin{array}{c}\qquad \max \\
\text { Liter.mol }{ }^{-1} \mathrm{~cm}^{-1}\end{array}$ & $\mathrm{Mp}{ }^{\circ} \mathrm{C}$ \\
\hline \multirow[t]{3}{*}{1} & Orange & 0.634 & 368.60 & 6340 & 209-211 \\
\hline & & 0.820 & $280.00(\mathrm{sh})$ & 8200 & \\
\hline & & 0.963 & 240.00 & 9630 & \\
\hline \multirow[t]{3}{*}{1} & Yellow & 1.921 & 368.60 & 19210 & $207-209$ \\
\hline & & 0.794 & 274.40 & 7940 & \\
\hline & & 1.363 & 231.2 & 13630 & \\
\hline \multirow[t]{3}{*}{2} & Yellow & 1.437 & 342.80 & 14370 & $90-92$ \\
\hline & & 1.191 & 298.40 & 11910 & \\
\hline & & 1.660 & 271.80 & 16600 & \\
\hline \multirow[t]{3}{*}{3} & Orange & 1.403 & 368.60 & 14030 & $210-212$ \\
\hline & & 1.100 & $275.00(\mathrm{sh})$ & 11000 & \\
\hline & & 1.750 & 237.40 & 17500 & \\
\hline \multirow[t]{3}{*}{3} & Yellow & 2.031 & 369.60 & 20310 & $205-207$ \\
\hline & & 0.871 & 274.40 & 8710 & \\
\hline & & 1.600 & $230.00(\mathrm{sh})$ & 16000 & \\
\hline
\end{tabular}

Table 2. Wavelength $(\lambda)$ of middle bands for Schiff bases in ethanol before and after addition of $0.01 \mathrm{~N} \mathrm{NaOH}$

\begin{tabular}{ccccc}
\hline $\begin{array}{c}\text { Schiff Base } \\
\text { Number }\end{array}$ & Colour & Original $\lambda(\mathrm{nm})$ & Final $\lambda(\mathrm{nm})$ & $\Delta \lambda(\mathrm{nm})$ \\
\hline 1 & Orange & 275.8 & 271.4 & -4.4 \\
& Yellow & 275.8 & 271.2 & -4.6 \\
\hline 2 & Yellow & 273.2 & 277.4 & +3.6 \\
\hline 3 & Orange & 275.8 & 270.4 & -5.4 \\
& Yellow & 272.2 & 266.2 & -6.0 \\
\hline
\end{tabular}

Table 3. IR $\left(\mathrm{cm}^{-1}\right)$ absorption bands for $10^{-3} \mathrm{M}$ Schiff bases numbers (1-3) and their isomers in DCM solvent

\begin{tabular}{|c|c|c|c|c|c|c|c|c|}
\hline \multirow{2}{*}{$\begin{array}{c}\text { Imine } \\
\text { No. }\end{array}$} & \multirow{2}{*}{ colour } & \multirow{2}{*}{ overtone } & \multicolumn{2}{|c|}{ H-bonding } & \multirow{2}{*}{$\mathrm{C}-\mathrm{H}$} & \multirow{2}{*}{$\mathrm{C}=\mathrm{O}$} & \multirow{2}{*}{$\begin{array}{l}\mathrm{Ph} \text { or } \\
\mathrm{C}=\mathrm{N}\end{array}$} & \multirow{2}{*}{$\mathrm{C}-\mathrm{N}$} \\
\hline & & & Inter & Intra & & & & \\
\hline \multirow[t]{2}{*}{1} & Orange & $3944-3691$ & $3618(\mathrm{~m})$ & $3552(\mathrm{w})$ & $3066(w)$ & 1720 & 1604 & 1265 \\
\hline & & $(\mathrm{s})$ or $(\mathrm{w})$ & & & 2993(w) & $(w)$ & (s) & $(\mathrm{s})$ \\
\hline \multirow[t]{2}{*}{1} & Yellow & $3944-3687$ & $3600(\mathrm{~m})$ & $3545(\mathrm{w})$ & $3066(w)$ & 1709 & 1604 & 1277 \\
\hline & & $(\mathrm{s})$ or $(\mathrm{w})$ & & & 2962(w) & $(w)$ & (s) & (s) \\
\hline \multirow[t]{2}{*}{2} & Yellow & $3944-3687$ & $3599(\mathrm{~m})$ & $3537(w)$ & $3078(w)$ & 1720 & 1604 & 1286 \\
\hline & & $(\mathrm{s})$ or $(\mathrm{w})$ & & & 2974(w) & (w) & (s) & (s) \\
\hline \multirow[t]{2}{*}{3} & Orange & $3944-3691$ & $3600(\mathrm{~m})$ & $3531(\mathrm{w})$ & $3078(w)$ & 1724 & 1604 & 1269 \\
\hline & & $(\mathrm{s})$ or $(\mathrm{w})$ & & & 2981(w) & $(w)$ & (s) & (s) \\
\hline \multirow[t]{2}{*}{3} & Yellow & $3944-3691$ & $3599(\mathrm{~m})$ & $3545(w)$ & $3066(w)$ & 1720 & 1604 & 1254 \\
\hline & & $(\mathrm{s})$ or $(\mathrm{w})$ & & & 2981(w) & $(\mathrm{w})$ & (s) & (s) \\
\hline
\end{tabular}

$\mathrm{DCM}=$ Dichloro methane 
In yellow isomers of Schiff bases (1 and 3), the first bands in these spectra had a greater intensities and molar extinction coefficients as compared with orange isomers. These results led to the conclusion that yellow colour isomers in these Schiff bases, represent the more stable, more planar anti isomers. The other orange colour isomers in the last Schiff bases, surely represent the less stable syn isomers. On the same basis, the yellow isomer in Schiff base (2), should exist in the anti stable form, as in Table 1.

2) The more planar anti yellow isomers in Schiff bases (1 and 3) had a lower melting points as compared with syn orange analogues as in Table 1. Hence these yellow isomers posses a less degrees of association or polymerization by intermolecular (Azzouz et al., 2003) hydrogen bonding existing in these isomers.

3) The IR spectra of $10^{-4} \mathrm{M}$ isomers Schiff bases (1-3) in dichloromethane (DCM) solvent as in Figure 2, showed the following stretching absorption bands:

a) The over tones bands of weak or strong absorption in the range (3944-3687) $\mathrm{cm}^{-1}$.

b) A medium and weak intensities intermolecular and intramolecular hydrogen bonding bands exist simultaneously in each isomers of types $\mathrm{N}-\mathrm{H}$...... N and $\mathrm{O}-\mathrm{H} . . . . \mathrm{N}$ respectively.

c) A weak intensities of C-H aliphatic or aromatic linkages in the range (3078-2961) $\mathrm{cm}^{-1}$.

d) A weak absorptions for carbonyl linkages in these Schiff bases isomers at wave number 1720. These originated from tautomerism reaction of type

\section{enol $\rightleftharpoons$ keto}

e) A strong absorptions for aromaticity or azomethine link in these Schiff bases isomers at wave number $1720 \mathrm{~cm}^{-1}$.

f) A strong absorption for C-N linkages in the range (1254-1286) $\mathrm{cm}^{-1}$ originated from presence of amino group $\mathrm{NH}_{2}$ attached on carbon atom on amine parts of Schiff bases at ortho, meta and para positions on ring.

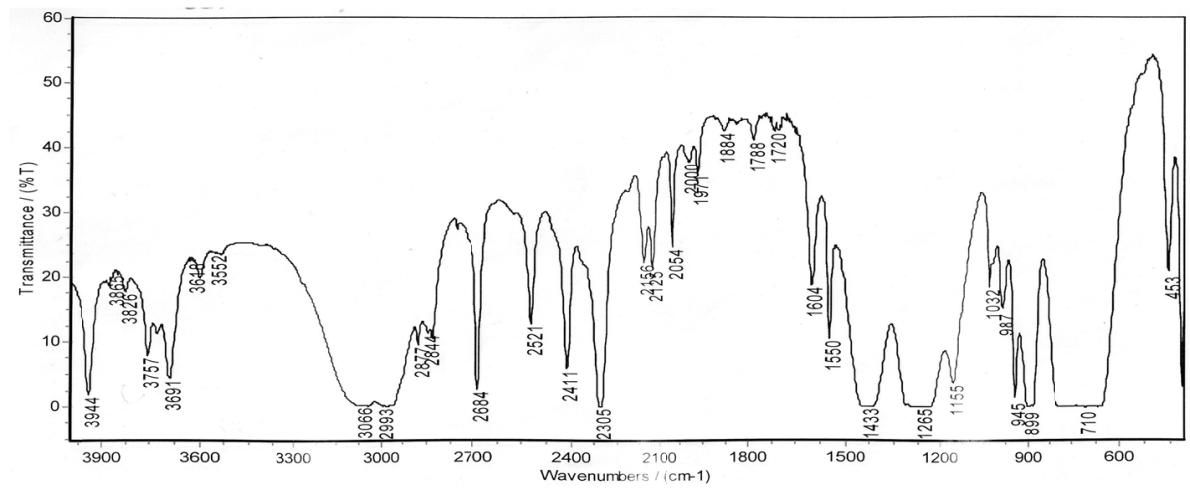

2a. Orange isomer of Schiff base 1

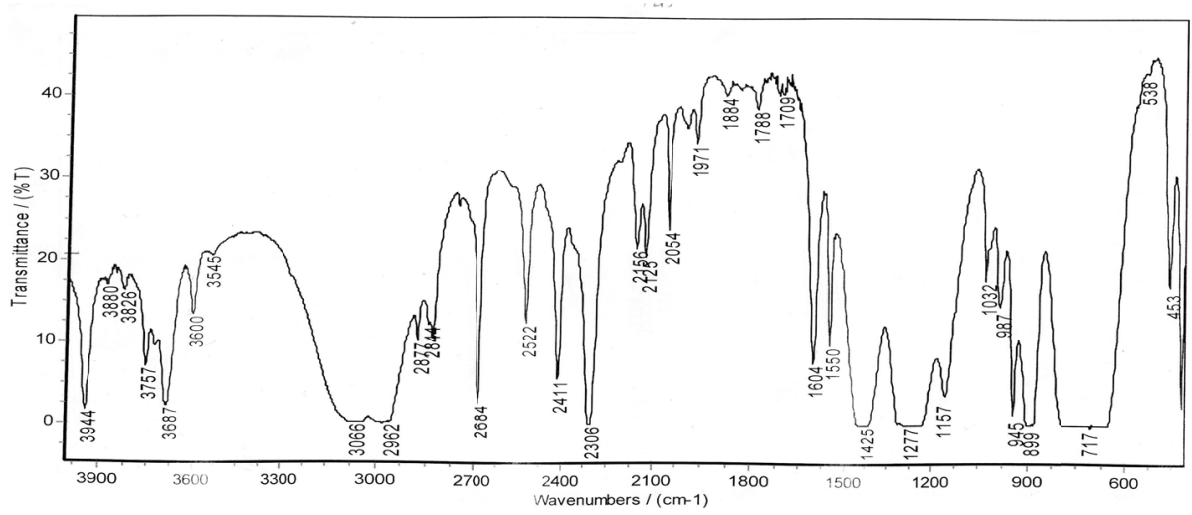

2b. Yellow isomer of Schiff base 1 


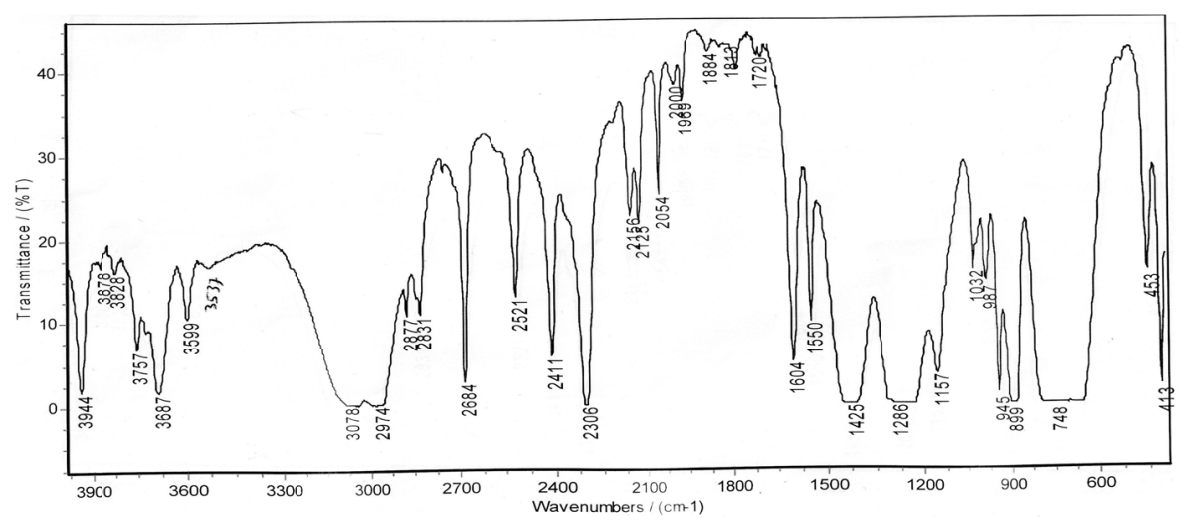

2c. Yellow isomer of Schiff base 2

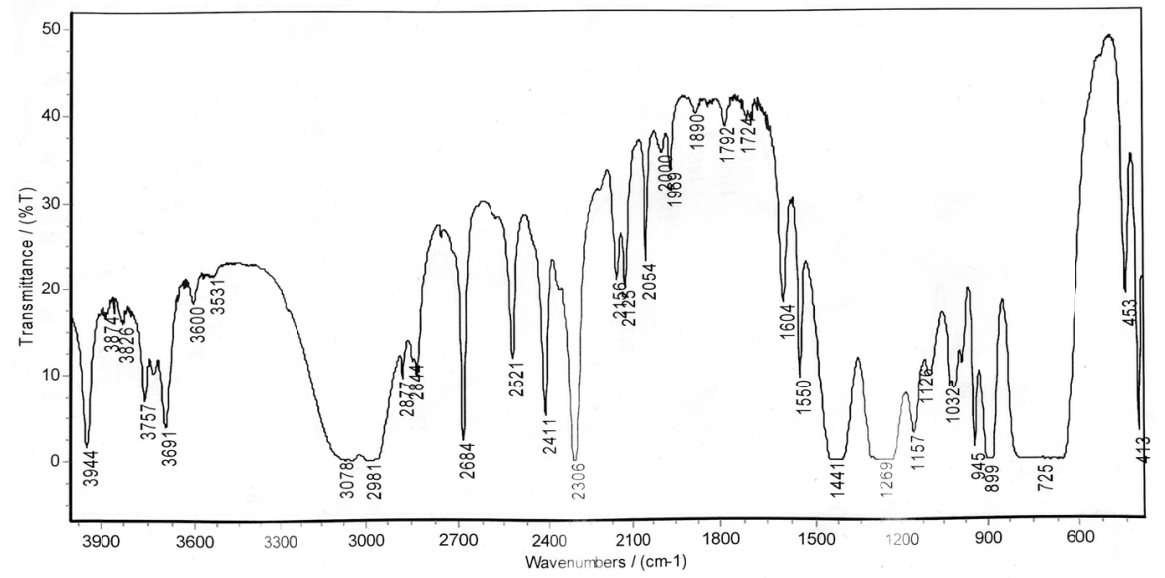

2d. Orange isomer of Schiff base 3

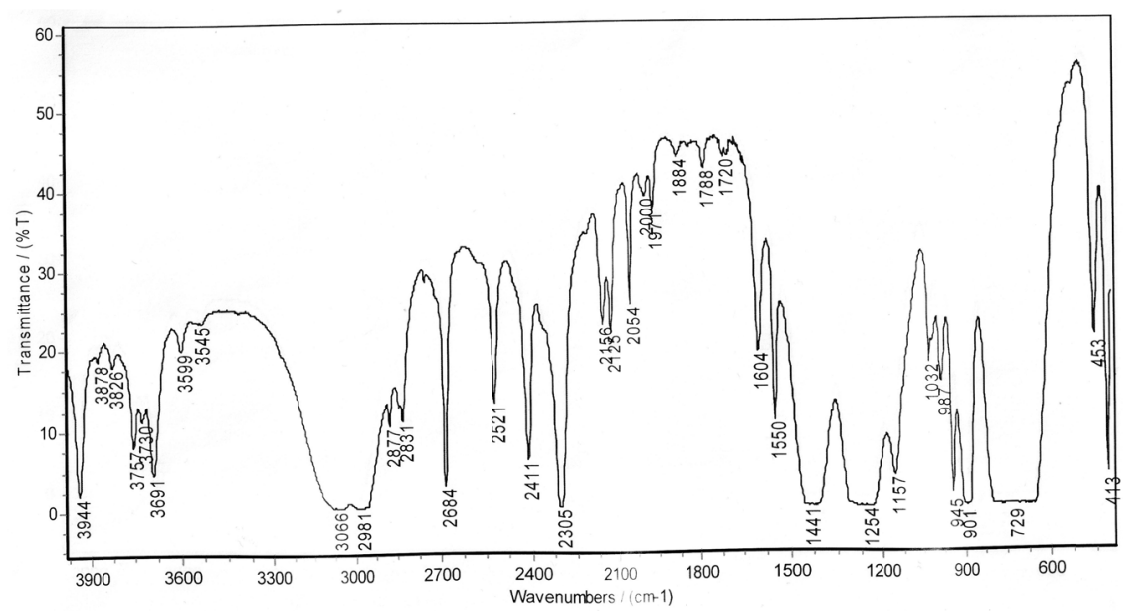

2e. Yellow isomer of Schiff base 3

Figure 2. IR Spectra of $10^{-4}$ in dichloromethane

These differences in UV-IR spectra and melting points collected in this study, confirm (Azzouz et al., 2003) the chemical structures syn and anti isomers existing in Schiff bases (1-3). They are in agreement (Majer et al., 1983) with other earlier study on syn and anti isomerism existing in aromatic aldoximes performed by mass spectrometric method.

These interested results on UV-IR spectra, encouraged the workers in this investigation to extend the study to further physical parameters on isomers as pKa values for ionization reaction of these Schiff bases. 
The pKa values for Schiff bases (1-3) and their yellow orange isomers were determined (Albert et al., 1974) successfully by potentiometric titration method. Results collected in this investigation were tabulated in Table 4.

Table 4. Comparison of pKa values for yellow and orange isomers of Schiff bases (1-3) in absolute ethanol

\begin{tabular}{|c|c|c|c|c|c|}
\hline \multirow{2}{*}{$\begin{array}{c}\text { Temp } \\
\text { (K) }\end{array}$} & \multicolumn{2}{|c|}{ Schiff base (1) } & \multirow{2}{*}{$\frac{\text { Schiff base (2) }}{\text { Yellow }}$} & \multicolumn{2}{|c|}{ Schiff base (3) } \\
\hline & Orange & Yellow & & Orange & Yellow \\
\hline 288 & 12.0020 & 12.7915 & 11.8544 & 12.4084 & 12.4642 \\
\hline 298 & 11.8443 & 12.7347 & 11.3599 & 12.1396 & 12.1644 \\
\hline 308 & 11.7687 & 11.6226 & 11.2250 & 11.1458 & 10.8718 \\
\hline 318 & 11.6422 & 11.2975 & 11.1415 & 10.8432 & 10.5985 \\
\hline 328 & 11.3856 & 11.2510 & 11.0688 & 9.6648 & 10.4774 \\
\hline
\end{tabular}

Table 4 showed the following results:

1) The acidities of Schiff base isomers were increased by increasing temperature. These mean a greater numbers of $\mathrm{H}+$ ion were liberated from ionization reactions of these Schiff bases.

2) Acidities of orange syn isomers of Schiff bases 1 and 3 were greater than their yellow anti analogues at temperatures $(288$ and 298$) \mathrm{K}$. Similar result was collected for orange isomer of Schiff base 3 at temperature (328) $\mathrm{K}$ as compared with yellow isomer. Conversely, the reverse of such results were true for Schiff bases 1 and 3 at other temperatures listed in Table 4.

3) Acidities of yellow isomer of Schiff base (2) were greater than acidities of orange and yellow isomers of Schiff base (1), at all temperatures stated. They were in agreement with orange and yellow isomers of Schiff base (3) at temperatures $288 \mathrm{~K}$ and $298 \mathrm{~K}$ only.

4) Maximum and minimum $\mathrm{pKa}$ of isomers in Table (4) had values 12.7915 and 9.6656 at a range of temperatures mentioned. These showed a difference value of $3.1259 \mathrm{pKa}$ unit.

This little number in difference could be raised from the following different factors available in Schiff base isomers during $\mathrm{pKa}$ study as follows:

1) The temperature range mentioned had a difference value of $40{ }^{\circ} \mathrm{C}$.

2) The presence of syn or anti isomers Schiff bases (1 and 3) and anti isomer alone in Schiff base (2).

3) The presence of amino group at ortho, meta and para positions on primary amine parts of Schiff bases (1-3).

It was supposed in this investigation that these three different factors just mentioned had a similar weight in determining the $\mathrm{pKa}$ value of any isomer. Hence, the weight of any factor equivalent to $3.1259 / 3=1.0419 \mathrm{pKa}$ unit.

This result came to near agreement (Azzouz et al., 2012) with other similar study in oxime having phenol and oxime groups, when $\mathrm{pK} 1$ for phenol and $\mathrm{pK} 2$ for oxime were determined potentiometrically in syn and anti isomers of 4-hydroxy benzaldoximes, having $\Delta \mathrm{pK} 1$ and $\Delta \mathrm{pK} 2$ values of 2.796 and 1.78 respectively.

\section{Discussion}

1) Salicylidene anilines Schiff bases having o, m, p-amino groups on aromatic amine groups as numbered $(1,2$ and 3$)$ were prepared by standard method.

2) Two orange and yellow colored isomers had been collected for Schiff bases (1 and 3) by fractional recrystallization. Schiff bases number 2 led to the formation of single yellow isomer.

3) The measurements of UV-IR spectra led to the presence of yellow and orange colors in Schiff bases (1 and 3 ) in the anti and syn isomers respectively. Meanwhile, Schiff bases 2 isomer was existed in the anti isomer form.

4) The anti isomers in these Schiff bases were considered to be more planar and less polymerized by aid of inter molecular hydrogen bonding, if compared with syn isomers.

5) The middle bands in UV spectra of orange and yellow colors isomer of Schiff bases (1 and 3) exist in 
zwitter ions, while the yellow isomer of Schiff bases 2 exist as nitrilium ion.

6) The yellow isomers of Schiff bases (1-3) represent the more stable anti forms. While the orange isomers of Schiff bases (1 and 3) represent the less stable syn forms.

\section{References}

Albert, A., \& Serjeant, E. P. (1974). The Determination of Ionization Constants (2nd ed.). London: Chapman and Hall.

Azzouz, A. S. P. (1995). Isomerism and Beckmann Rearrangement Reactions of $\alpha$-Benzilmonoxime. A Comparative Kinetic and Stability Study. Spectroscopy Letters, 28(1), 1-9. http://dx.doi.org/10.1080/003870195080116

Azzouz, A. S. P., \& AL-Bakzo, D. P. (2012). Phy. Chem. An Indian J., 7(1), 2.

Azzouz, A. S. P., \& Kashmola, B. O. (2011). Nat. J. Chem., 41, 1.

Azzouz, A. S. P., Othman, S. S., \& Dabagh, A. N. A. (2009). Nat. J. Chem., 36, 782.

Azzouz, A. S. P., Rahmann, A. A., \& Taki, A. G. (2003). Determination of imines structures derived from 2-hydroxy-1-napthaldehyde. J. Edu. Sci., 15(2), 1.

Azzouz, A. S. P., \& Sulaman, R. D. (2013). Asian J. Chem., 25(10), 5303.

EL-Bayoumi, M. A., EL-Aasser, M., \& Halim, A. (1971). Electronic spectra and structures of Schiff bases. J. Am. Chem. Soc., 93, 586. http://dx.doi.org/10.1021/ja00732a004

EL-Bindary, A. A., \& EL-Sonbati, A. Z. (1979). Gazz. Chim. Ital., 127, 597.

Majer, J. R., \& Azzouz, A. S. P. (1983). J. Chem. Soc. Farad. Trans. 1, 79, 675.

Patai, S. (1970). The chemistry of carbon Nitrogen Double Bond. New York: Wiley. http://dx.doi.org/10.1002/9780470771204

Saeed, A. A. H. (1984). Preparation and molecular structure of new cyclic .beta.-diketone Schiff bases. J. Chem. Eng. Data, 29, 358. http://dx.doi.org/10.1021/je00037a042

Saeed, A. A. H., \& Matti, G. T. (1979). Indian J. Chem., 1813, 338.

Saeed, A. A. H., Othman, S. A. W., AL-Jalil, K. A., \& Abo, A. T. (1981). Can. J. Spectrosc., 26, 38.

Saeed, A. A. H., Sultan, A.W., Selman, S. A., \& Abood, N. A. (1983). Can. J. Spectrosc., $28,104$.

Vogel, A. F. (1978). Text Book of Practical Organic Chemistry (4th ed.). London: Longman.

\section{Copyrights}

Copyright for this article is retained by the author(s), with first publication rights granted to the journal.

This is an open-access article distributed under the terms and conditions of the Creative Commons Attribution license (http://creativecommons.org/licenses/by/3.0/). 